\title{
HAS AUSTRALIA'S FLOATING EXCHANGE RATE REGIME \\ BEEN OPTIMAL?
}

\author{
Anthony J. Makin* \\ Economics, Griffith Business School \\ Griffith University \\ Gold Coast, 4222 \\ Australia \\ t.makin@griffith.edu.au \\ Nicholas Rohde \\ Economics, Griffith Business School \\ Griffith University \\ Gold Coast, 4222 \\ Australia
}

March 2012

* corresponding author

Acknowledgement: The authors wish to acknowledge the constructive comments made by the reviewers. 


\title{
HAS AUSTRALIA'S FLOATING EXCHANGE RATE REGIME BEEN OPTIMAL?
}

\begin{abstract}
This paper develops a straightforward theoretical framework for evaluating exchange rate regime choice for small economies. It proposes that a floating exchange rate minimises national income and employment variation when real macroeconomic shocks predominate, whereas a pegged exchange rate achieves this goal should money demand shocks predominate. It then shows econometrically that, in the case of Australia, a floating exchange rate best suited the economy for the period 1985 to 2010, because real shocks were more significant than monetary shocks. Moreover, consistent with the theory, further results showing that a stronger (weaker) exchange rate correlated with positive (negative) deviations from trend GDP affirm that a floating exchange rate regime was optimal for Australia over this time.
\end{abstract}

Keywords: real shocks, monetary shocks, national income, exchange rate regime, Australia

JEL Classification: F31, F33, F41 


\section{HAS AUSTRALIA'S FLOATING EXCHANGE RATE REGIME BEEN OPTIMAL?}

\section{Introduction}

Exchange rate regimes are pivotal to explaining macroeconomic behaviour in highly internationally integrated economies, irrespective of their level of development. Although an earlier literature explored the topic of exchange rate choice with reference to macroeconomic fundamentals (see for instance Boyer 1978, Melvin 1985, Bosco 1987, Genbeg 1989, Eichengreen 1995 and Garber and Svennson 1995), with the exception of a few papers exploring why emerging countries choose not to float, (see Hausmann et al 2001 and Calvo and Reinhardt 2002), there has been a paucity of theoretical and empirical literature on this topic over recent years. This perhaps reflects the findings of influential surveys there were no simple prescriptions for adopting any particular regime (see Mussa et al 2000 and Rogoff et al 2004).

Yet the need to understand which exchange rate regime best suits an economy remains very important, especially since globalisation of goods, services and financial markets has increased the magnitude and frequency of external shocks over recent decades. Whereas central banks in some economies in the fast growing Asia-Pacific region, such as the United States, Australia and New Zealand, have allowed floating exchange rates to insulate their economies from external shocks, monetary authorities in others, such as China, Hong Kong SAR and Singapore, have maintained highly inflexible exchange rates. 
Since Australia's exchange rate was floated in the early 1980s, the Australian dollar has become one of the ten most actively traded currencies in the world, disproportionately higher than the economy's relative size in the global economy. Floating the Australian dollar afforded the central bank control of the domestic money stock which, under a pegged system, is endogenous. A large literature (for instance, see Frenkel 1976, Branson and Henderson 1985, Frenkel and Mussa 1985, Mark 1985, McDonald 1999, and Sarno and Taylor 2002) suggests that the money demandsupply relationship is a key determinant of the exchange rate under a floating regime.

On the real side, a feature the Australian economy shares with many emerging economies is that it exports mainly primary and lightly processed agricultural and mineral commodities whose world prices are highly variable, yet mostly imports manufactured goods whose world prices are stable in the short run. As Australia is a relatively small trading nation, the value of its exports and imports depend on prices set in world markets. Volatility of its export commodity prices exposes the economy to major fluctuations in its terms of trade, the ratio of export to import prices.

This paper contributes to the literature on the macroeconomics of exchange rates in two ways. First, it proposes a theoretical basis for choosing a small economy's exchange rate regime, and second, it empirically examines whether Australia, as a case study, has adopted the regime that best suits its macroeconomic characteristics. The next section models the inter-relationships between the exchange rate and the real and monetary sectors of a small open economy. Section 3 establishes a criterion for choosing the optimal exchange rate system. Section 4 then empirically examines the behaviour of the Australian dollar between 1985 and 2010 showing, in two different 
ways, that a floating exchange rate best suited the economy over this period. The final section highlights the main findings and implications for policy.

\section{An International Macroeconomic Framework}

Contemporary international macroeconomic models are usually based on microeconomic foundations populated by optimising representative agents with rational expectations in the tradition of Obstfeld and Rogoff (1996). Dynamic stochastic general equilibrium (DSGE) models within this paradigm however are quite sensitive to underlying assumptions, such as the nature of utility functions (Sarno and Taylor 2003), and their inherent complexity obscures lessons for macroeconomic policymakers about optimal exchange rate choice. In contrast, conventional aggregative approaches such the still popular Mundell (1963) - Fleming (1962) model yield straightforward results that remain central to the body of international macroeconomic theory.

The following model focuses on exchange rate behaviour with reference to those key macro variables of most interest to policymakers, without recourse to microeconomic foundations, and so is in the Mundell-Fleming tradition. Extending precepts of that approach, it examines exchange rate choice in a way that also parallels Poole's (1970) classic analysis of monetary policy choice between interest rate and money stock targets. In developing the framework, we begin with the real side and then moves to the monetary side, invoking numerous standard macroeconomic behavioural relations. 


\subsection{Real Sector Linkages}

National income equals expenditure on consumption, investment, and exports less imports. Hence,

$$
y=c(y)+i(r)+x\left(e, p_{x}^{*}\right)-m\left(e, y, p_{M}^{*}\right)
$$

where

$y$ is real gross national income

$c$ is private and public consumption

$i$ is public and private investment

$r$ is the real interest rate

$x$ is exports of goods and services

$e$ is the effective exchange rate

$p_{X}^{*}$ is an index of world prices received for exports

$m$ is imports of goods and services

$p_{M}^{*}$ is an index of world prices paid for imports

Next real consumption, investment, exports and imports are assumed to behave as follows.

$$
\begin{array}{ll}
c=\bar{c}+\alpha y & 0>\alpha>1 \\
i=\bar{i}-\gamma r & \\
x=\bar{x}+\xi e+\lambda p_{X}^{*} & \\
m=\bar{m}+\mu y-\varsigma e+\nu p_{M}^{*} & O>\mu>1
\end{array}
$$

where

$\bar{c}, \bar{i}, \bar{x}, \bar{m}$ represent autonomous consumption, investment, exports and imports in constant price terms, 
$\alpha$ is the marginal propensity to consume,

$\gamma$ gauges the responsiveness of investment to the real interest rate,

$\xi$ is the responsiveness of export volumes to the exchange rate,

$\lambda$ is the pass-through of world export prices, $p_{X}^{*}$, to the value of exports, $\mu$ is the marginal propensity to import,

$\varsigma$ is the responsiveness of import volumes to the exchange rate,

$v$ is the pass-through of world import prices, $p_{X}^{*}$, to the value of imports

Equation (2) conventionally suggests that apart from an autonomous component, which includes government spending, movements in national income influence short run consumption spending, whereas equation (3) proposes that the real term interest rate affects investment. Equations (4) and (5) show that real export and import values respond to exchange rate movements which alter competitiveness in the short run, so that currency depreciation raises exports and lowers imports. World prices received for exports and world prices paid for imports also influence exports and imports according to the degree to which they pass through to export and import values.

Summing relations (2)-(5), and solving for $y$ yields

$$
y=\frac{\left(\bar{c}+\bar{i}+\bar{x}-\bar{m}+(\xi+\varsigma) e-\gamma r+\lambda p_{X}^{*}-v p_{M}^{*}\right.}{(1+\mu-\alpha)}
$$

Since we assume short run variation in the terms of trade arises from export commodity price volatility, consistent with the experience of many commodity exporters, rather than from import prices, the foreign currency price deflator for importables is set at its base year value $\left(\mathrm{p}_{\mathrm{M}}^{*}=1\right)$. 
Dividing (6) through by $\mathrm{p}_{\mathrm{M}}^{*}$, noting that for a small open economy the exogenous terms of trade, ToT, is the ratio $p_{X}^{*} / p_{M}^{*}$ and that, via interest parity, the domestic interest rate equals the world interest rate, $r^{*}$, expression (6) becomes

$$
y=\frac{(\bar{c}+\bar{i}+\bar{x}-\bar{m})-\gamma r^{*}-v+(\xi+\varsigma) e+\lambda T o T}{(1+\mu-\alpha)}
$$

Partially differentiating (7) with respect to the effective exchange rate yields

$$
\partial y / \partial e=\frac{\xi+\varsigma}{1+\mu-\alpha}>0
$$

This result implies national output and employment is positively related to the exchange rate in the short run and that the terms of trade is a shift factor since

$$
\partial y / \partial T o T=\frac{\lambda}{1+\mu-\alpha}>0
$$

Expression (7) provides a basis for analysing short run national income and employment determination in exchange rate - national income space. Since $\partial y / \partial e>0$, this allows us to draw an upward sloping schedule, labelled the $Y Y$ schedule in Figure 1. 


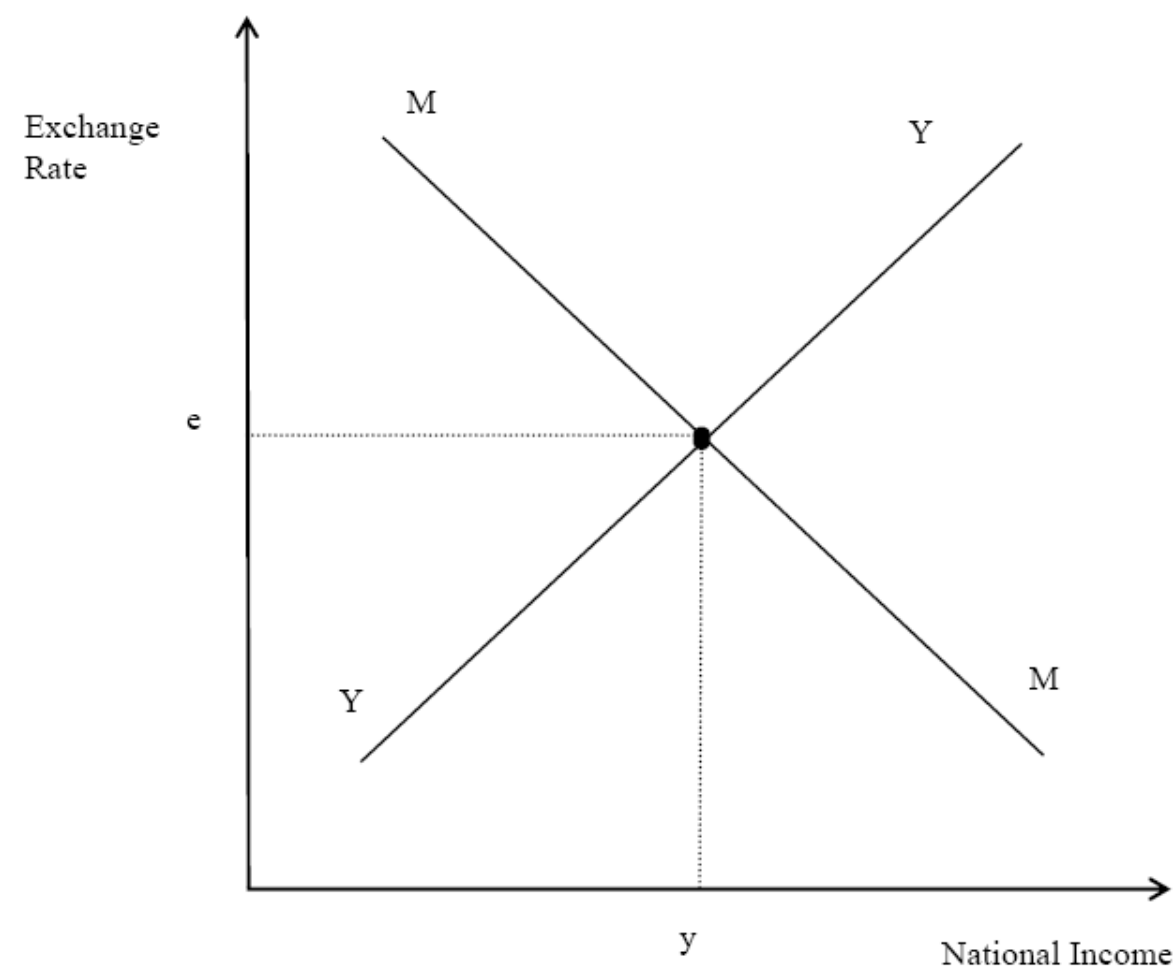

Figure 1 - General Equilibrium

\subsection{Monetary Sector Linkages}

On the monetary side of the economy, the real demand for cash balances, $L$, equals the real money supply, so that

$$
L(y, r)=\frac{M}{P}
$$

Money demand depends positively on national income according to the parameter, $\kappa$, and negatively on the short run interest rate, according to the parameter $\eta$, such that,

$$
\frac{M}{P}=\kappa y-\eta r \quad \kappa>0, \quad \eta>0
$$

The domestic interest rate, $r$, is related to the foreign interest rate via interest parity, expressed as

$$
r=r^{*}
$$

where $r^{*}$ is the foreign interest rate. 
The national price level is a weighted measure of the price of domestic goods and services, $P_{d}$, as well as the foreign currency price of imported goods and services, $P_{M}^{*}$ , converted to domestic currency via the exchange rate,

$$
P=\sigma P_{d}+(1-\sigma) e P_{M}^{*}
$$

Substituting (12) and (13) into (10) and solving for e, yields

$$
\mathrm{e}=\left[\frac{\mathrm{M}}{\kappa y-\eta\left(\mathrm{r}^{*}+\varphi\right)}-\sigma \mathrm{P}_{\mathrm{d}}\right] /(1-\sigma) \mathrm{P}_{\mathrm{M}}^{*}
$$

Partially differentiating (14) with respect to the nominal exchange rate, we find

$$
\partial e / \partial y<0
$$

This implies a downward sloping schedule, labelled the $M M$ schedule, can be drawn in exchange rate-national income space in Figure 1. Relation (13) also allows us to identify domestic money demand shocks as the key stochastic shift factor, consistent with Poole's (1970) analysis of optimal monetary choice in the closed economy context

since $\partial \mathrm{e} / \partial \kappa<0, \quad \partial \mathrm{e} / \partial \eta<0$

\section{Exchange Rate Regime Choice}

The framework can now be used to examine whether a fixed or floating exchange rate best suits an economy in light of the shocks it experiences. If for instance the economy is more susceptible to terms of trade shocks due to world commodity price fluctuations than money demand shocks, as shown in Figure 2, the $Y Y$ schedule would shift around its trend value in the short run, with the $M M$ schedule remaining 
relatively stable. Under these circumstances an exchange rate appreciation (depreciation) is associated with a rise (fall) in national income.

Alternatively, if the exchange rate is pegged, the money supply is endogenous and national income varies between $\mathrm{y}_{1}$ and $\mathrm{y}_{2}$ around its trend value, $y_{0}$, whereas if the exchange rate floats, national income and hence employment would vary less, between $y_{1}^{\prime}$ and $y_{2}^{\prime}$. Therefore, a floating exchange rate is superior to a pegged rate because it insulates the economy from unnecessary income and associated employment fluctuation.

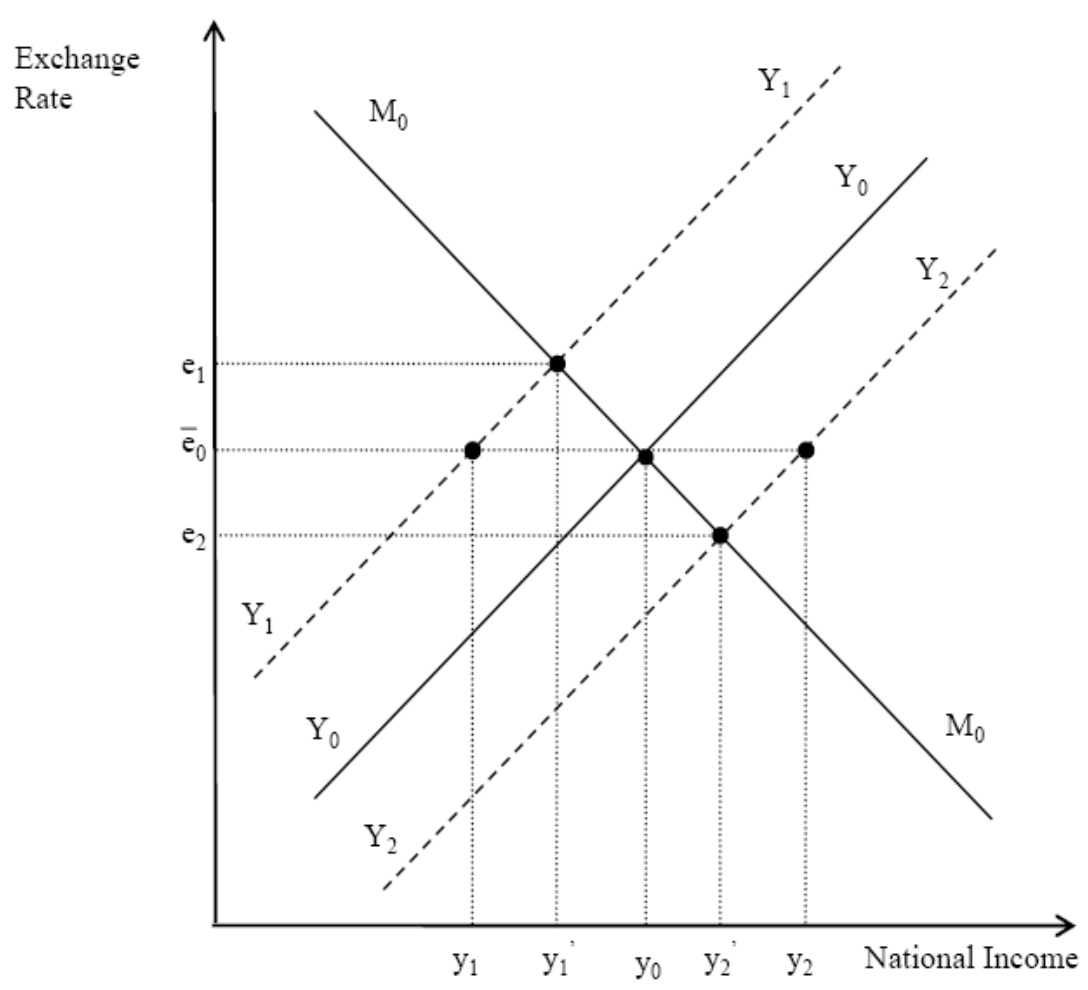

Figure 2 - Real Shocks and National Income Variation 
However, if the economy is more prone to money demand shocks, the $M M$ schedule would shift about relative to the $Y Y$ schedule, as shown in Figure 3. Opposite to the above result, if money demand shocks predominate, an exchange rate appreciation (depreciation) is associated with a fall (rise) in national income and employment. Under these circumstances, a pegged exchange regime stabilizes both the exchange rate $\left(\right.$ at $\bar{e}_{0}$ ) and national income (at $y_{0}$ ), whereas a floating regime implies unnecessary variation in both, as well as employment. Hence, a pegged exchange rate is preferable.

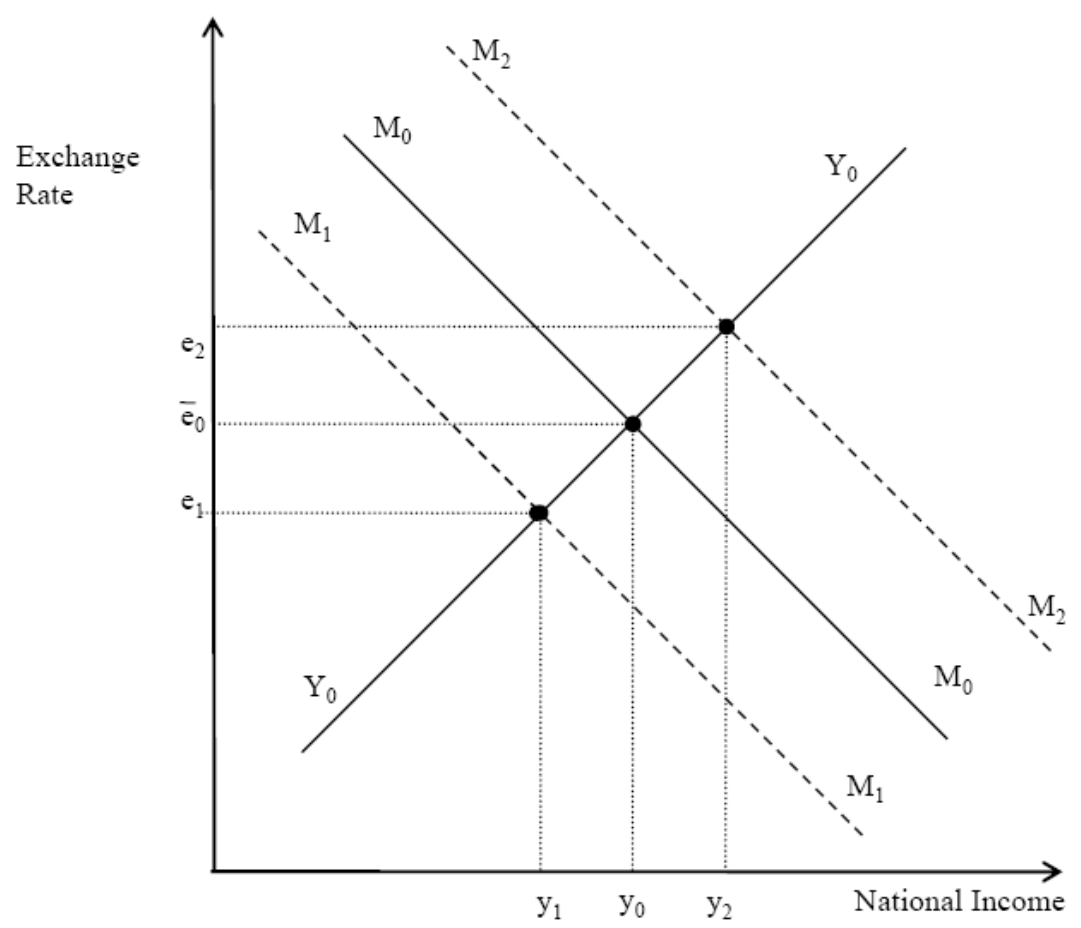

Figure 3 - Monetary Shocks and National Income Variation

This analysis yields the following general conclusion about exchange rate choice: for any small economy, a floating exchange rate best minimises national income and employment variation if real shocks predominate, whereas a pegged exchange rate best achieves this if money demand shocks predominate. 


\section{Australia's Floating Experience: An Econometric Analysis}

With the above proposition in mind, we now empirically examine Australia's exchange rate experience between 1985 and 2010; first by identifying whether real or monetary shocks were more significant, and second, by testing whether the exchange rate and real GDP were related as the theory suggests over this period.

\subsection{Properties of the Data}

To determine the influence of real and monetary factors on Australia's effective exchange rate we use real quarterly data from 1985 to 2010 with a total of 100 observations included. The estimated results are insensitive to small changes to the length of the sample. The quarterly exchange rate series is the three month average of average Real Trade Weighted Index (RTWI) monthly data sourced from the Bank for International Settlements database. As published, the effective exchange rate is the inverse of the way the exchange rate as defined in the theoretical exposition above. Hence, a rise in the RTWI signifies exchange rate appreciation.

Quarterly data for the monetary aggregate (M3) is sourced from the Reserve Bank of Australia database, whereas Real Gross Domestic Product (RGDP), the Terms of Trade (ToT) and the implicit price deflator for M3 are sourced from Australian Bureau of Statistics National Accounts series (Catalogue 5206.0). The real GDP series is seasonally adjusted data for each quarter.

All four series are tested for unit roots in levels and differences. For the sake of robustness we employ three cointegration tests, the Augmented Dickey Fuller (ADF) 
test (Said and Dickey, 1984), Generalized Augmented Dickey Fuller test (GLS-ADF) (see Elliot, Rothenberg, and Stock, 1996) and the Philips Peron (PP) test (Phillips and Perron, 1988). The general testing procedure is of the Dickey Fuller (Dickey and Fuller, 1979) form

$$
\Delta x_{t}=\alpha+\delta t+\lambda x_{t-1}+v_{t}
$$

where significant negative estimates for parameter $\gamma$ imply stationarity. The ADF test operates upon the DF principle but controls for serial correlation by including lagged differences of the dependent variable in the test equation, where the lag length is determined by employing the Schwartz information criterion. The GLS-ADF test also applies this concept, but to data detrended using a generalized least squares procedure. The Phillips-Peron test provides non-parametric corrections for the test statistic in the presence of autocorrelation rather than the inclusion of lags. Test statistics and critical values for each test are provided in Tables $1-4^{1}$.

Table 1. Test statistics, critical values of unit root tests, RTWI Q3 1985- Q2 2010

\begin{tabular}{ccccccccc}
\hline \hline & \multicolumn{4}{c}{ RTWI } & \multicolumn{5}{c}{$\Delta R T W I$} \\
\hline & $\tau$ & $1 \%$ & $5 \%$ & $10 \%$ & $\tau$ & $1 \%$ & $5 \%$ & $10 \%$ \\
\hline ADF & -2.1292 & -4.0554 & -3.4568 & -3.1543 & -8.0902 & -4.0554 & -3.4568 & -3.1543 \\
GLS-ADF & -2.1889 & -3.5914 & -3.0396 & -2.7490 & -8.1602 & -3.5914 & -3.0396 & -2.7490 \\
PP & -1.7897 & -4.0544 & -3.4563 & -3.1540 & -7.9355 & -4.0554 & -3.4568 & -3.1543 \\
\hline \hline
\end{tabular}

\footnotetext{
${ }^{1}$ Test statistics and critical values are provided for specifications with intercepts and trends as per equation (1). Similar results can be found for less general specifications.
} 
Table 2. Test statistics, critical values of unit root tests, ToT Q3 1985 - Q2 2010

\begin{tabular}{ccccccccc}
\hline \hline & \multicolumn{4}{c}{ ToT } & \multicolumn{4}{c}{$\Delta$ ToT } \\
\hline \hline & $\tau$ & $1 \%$ & $5 \%$ & $10 \%$ & $\tau$ & $1 \%$ & $5 \%$ & $10 \%$ \\
\hline ADF & 0.2760 & -4.0565 & -3.4573 & -3.1546 & -6.0434 & -4.0544 & -3.4573 & -3.1546 \\
GLS-ADF & -0.1471 & -3.5952 & -3.0428 & -2.7520 & -4.7652 & -3.5914 & -3.0396 & -2.7490 \\
PP & -0.1877 & -4.0534 & -3.4558 & -3.1537 & -3.0406 & -4.0544 & -3.4563 & -3.1540 \\
\hline \hline
\end{tabular}

Table 3. Test statistics, critical values of unit root tests, M3 Q3 1985 - Q3 2010

\begin{tabular}{ccccccccc}
\hline & \multicolumn{4}{c}{$M 3$} & \multicolumn{5}{c}{$\Delta M 3$} \\
\hline \hline ADF & -2.0751 & -4.0544 & -3.4563 & -3.1540 & -8.7153 & -4.0544 & -3.4563 & -3.1540 \\
GLS-ADF & -2.0729 & -3.5876 & -3.0364 & -2.7460 & -8.4504 & -3.5876 & -3.0364 & -2.7460 \\
PP & -1.9535 & -4.0534 & -3.4558 & -3.1537 & -8.7075 & -4.0544 & -3.4563 & -3.1540 \\
\hline \hline
\end{tabular}

Table 4. Test statistics, critical values of unit root tests, RGDP Q3 1985 - Q3 2010

\begin{tabular}{ccccccccc}
\hline \hline & \multicolumn{4}{c}{$R G D P$} & \multicolumn{4}{c}{$\Delta R G D P$} \\
\hline \hline ADF & -1.9671 & -4.0534 & -3.4558 & -3.1537 & -8.3018 & -4.0544 & -3.4563 & -3.1540 \\
GLS-ADF & -0.5477 & -3.5838 & -3.0332 & -2.7430 & -8.1470 & -3.5876 & -3.0364 & -2.7460 \\
PP & -1.9766 & -4.0534 & -3.4558 & -3.1537 & -8.2863 & -4.0544 & -3.4563 & -3.1540 \\
\hline \hline
\end{tabular}

Comparing the test statistics to the critical values indicates that all variables exhibit unit roots as in no instances are we able to reject the null of a unit root in levels at $10 \%$ significance. Conversely all series appear to be stationary in first differences with rejection of the null usually at $1 \%$ or $5 \%$ significance, leading to the conclusion that all series are integrated of order $1^{2}$.

\footnotetext{
${ }^{2}$ It is noted that there is some debate over whether a unit root is present in typical output series. Authors such as Nelson and Plosser (1982) and Pappel and Prodan (2002) give a good account of this literature.
} 


\subsection{Real versus Monetary Influences on the Exchange Rate}

Initially we consider only the real TWI, ToT and real M3. Economic theory suggests that a long-run relationship between these variables is plausible and that RTWI and ToT will be positively related while RTWI and deflated M3 will be negatively related. We are interested in determining which of these factors is more influential (over a long time period) for the levels of Australia's trade weighted index and use a similar approach to avoiding the identification problem as that used by Makin and Narayan (2008) in estimating determinants of the United States' current account deficit.

Given that all series appear to be $\mathrm{I}(1)$ there is the potential for some type of cointegrating relationship(s) to exist. Such a relationship would allow for the relative sensitivities of the exchange rate to real and monetary factors to be estimated. We are specifically interested in the possibility of a single cointegrating equation of the general functional specification:

$$
R T W I_{t}=\beta_{0}+\beta_{1} T_{o T}+\beta_{2} M 3_{t}+e_{t}
$$

This equation is estimated and the residuals are checked for stationarity using the Engle-Granger (Engle and Granger, 1987) and PP (Phillips and Ouliaris, 1990) procedures, where rejection of the null hypothesis implies a cointegrating relationship is found. Again both tests are also built around the DF mechanism but differ in their account of autocorrelation in lagged residual terms.

For robustness we also conduct tests on rearrangements of Equation (18) with ToT and M3 as the dependent variable, although given the analysis we wish to conduct Equation (18) appears the most logical specification. MacKinnon (1996) P values 
from estimated $\tau$ and $z$ test statistics ( $z$ applied to a normalized autocorrelation coefficient) are given for the tests in the table below.

Table 5. Cointegration tests for equation (18)

\begin{tabular}{clcccc}
\hline \hline Dependent Variable & \multicolumn{1}{c}{ Test } & $\tau$ & $z$ & $p-(\tau)$ & $p-(z)$ \\
\hline \hline TWI & Engle-Granger & -5.0414 & -52.0054 & 0.0016 & 0.0000 \\
TWI & Phillips-Ouliaris & -4.0347 & -29.3662 & 0.0302 & 0.0175 \\
ToT & Engle-Granger & -3.3248 & -26.2296 & 0.1459 & 0.0351 \\
ToT & Phillips-Ouliaris & -2.6351 & -15.1779 & 0.4216 & 0.2890 \\
M3 & Engle-Granger & -3.8336 & -31.0638 & 0.0496 & 0.0117 \\
M3 & Phillips-Ouliaris & -3.4200 & -22.1226 & 0.1213 & 0.0829 \\
\hline \hline
\end{tabular}

When RTWI and M3 are the dependent variable we reject the null hypothesis of no cointegration at $10 \%$ and $5 \%$ significance levels in most cases, while for ToT we reject using the Engle Granger test and $z$ coefficients but not for the other tests ${ }^{3}$. We conclude that the linear combination of these variables is $\mathrm{I}(0)$ and that the estimated relationship is valid over the time period.

The cointegrating equation is estimated and the coefficients are provided in Table 6 . Alongside are $T$ statistics and $p$ values obtained using Newy-West standard errors which are consistent in the presence of heteroskedastic and autocorrelated errors. Given that cointegration implies parameter stability we are able to produce elasticity estimates based on regression coefficients that should apply over the entire sample. Elasticities are estimated at the means of the sample using the equations $\hat{\eta}_{\text {TOT }}=$ $\hat{\beta}(\overline{R T W I} / \overline{T o T})$ and $\hat{\eta}_{M 3}=\hat{\beta}(\overline{R T W I} / \overline{M 3})$ while average partial effects are also determined as $\hat{\eta}^{*}{ }_{T o T}=\frac{1}{t} \sum_{i=1}^{t} \hat{\beta}\left(R T W I_{i} / T o T_{i}\right)$ and $\hat{\eta}_{M 3}^{*}=\frac{1}{t} \sum_{i=1}^{t} \hat{\beta}\left(R T W I_{i} / M 3_{i}\right)$.

\footnotetext{
${ }^{3}$ These tests also indicate cointegration if the data is truncated atQ2 2008 prior to the financial crisis.
} 
The asterisk notation is used to differentiate between elasticities at the means and the means of the elasticities. We also estimate the elasticities directly by respecifying Equation (18) in terms of logged variables such that the coefficients are interpretable as percentage changes. We note that the cointegrating relationship still holds after this transformation albeit with slightly weakened significance. The direct elasticities are denoted $\hat{\eta}^{d}$ in Table 6 .

Table 6. Regression coefficients and elasticity estimates

\begin{tabular}{ccccccc}
\hline \hline & Coefficients & T Statistics & $p-$ value & $\hat{\eta}$ & $\hat{\eta}^{*}$ & $\hat{\eta}^{d}$ \\
\hline \hline Constant & 75.9492 & 10.288 & 0.0000 & - & - & - \\
ToT & 0.44390 & 4.9617 & 0.0000 & 0.3398 & 0.3390 & 0.3690 \\
M3 & -28.2248 & -2.1883 & 0.0031 & -0.1545 & -0.1581 & -0.1546 \\
\hline
\end{tabular}

The regression coefficients are of the expected signs and are significantly different from zero. The model also appears to fit the data reasonably well with an $R^{2}$ value of 0.52. The p-values indicate that the terms of trade was a more significant factor in explaining the trade weighted index than our monetary aggregate. This is consistent with the elasticity estimates which indicate that a percentage increase in the terms of trade coincides with an appreciation in the trade weighted index around $0.34 \%-0.37 \%$.

Conversely a percentage increase in the deflated M3 aggregate corresponds with a depreciation of around $0.15 \%-0.16 \%$ in the exchange rate. Further we conduct a simulation of the impact of a one standard deviation change in each of the explanatory variables upon RTWI. Standard deviations of the RHS variables are determined as $\hat{\sigma}_{T o T}=15.71$ and $\hat{\sigma}_{M 3}=0.1089$ and we use $\hat{\sigma}_{T o T} \times \hat{\beta}_{1}=6.973$ and $\hat{\sigma}_{M 3} \times \hat{\beta}_{2}=$ -3.074 to estimate the relative impacts. As the magnitude of the former effect is more than twice the latter this supports the proposition that the real channel has greater impact upon exchange rates than the monetary channel. 
There are two caveats that apply to the results. Firstly there is some co-linearity between the regressors ${ }^{4}$ which may affect the parameter estimates, though this influence is likely to be small given the minimal relationship found using an auxiliary regression. Secondly there is the potential for endogeneity bias for the estimates which measure the impact of M3 is possible. To examine this impact we repeated the estimation using 2SLS (2 Stage least Squares) employing lagged values as an instruments. This resulted in negligible changes in the relevant elasticity estimates.

\subsection{Short-term relationship between the real trade weighted index and real GDP}

The empirical analysis so far reveals that variation in Australia's terms of trade have more significantly determined exchange rate behaviour than variation in the money stock, providing evidence that a floating exchange rate has best suited the Australian economy over this period. However, there is an alternative approach to testing the optimality of Australia's exchange rate that complements the above. It involves directly testing the relationship between the RTWI and changes in real GDP in accordance with the theoretical framework.

Recall that if the Australian economy predominantly experienced real shocks, then quarterly rises (falls) in national income above trend growth would mainly be associated with appreciations (depreciations), since exchange rate appreciations (depreciations) are associated with rightward (leftward) shifts of the $Y Y$ schedule. Alternatively, if the economy mainly experienced monetary shocks, depreciations (appreciations) would, oppositely, be associated with rightward (leftward) shifts of the $M M$ schedule. In other words, the nominal exchange rate should be positively

\footnotetext{
${ }^{4}$ An auxiliary regression of ToT on a constant and M3 reveals a significant relationship ( $\left.\mathrm{p}=0.058\right)$ but a low coefficient of determination of 0.08 .
} 
correlated with RGDP if output is primarily driven by real-side factors, and negatively correlated if output is driven by monetary factors.

Estimating the relative magnitudes of these effects is complicated by endogeneity bias, however as the effects push in opposing directions we can estimate their relative influence. As Engle-Granger and Phillips-Ouliaris tests fail to reject the null of no cointegration between these variables the relationship may be estimated appropriately in differences. To model we allow for the general ARDL process

$$
\Delta R T W I_{t}=\beta_{0}+\sum_{j=1}^{k} \alpha_{j} \Delta R T W I_{t-j}+\sum_{p=1}^{q} \delta_{p} \Delta R G D P_{t+1-q}+e_{t}
$$

where $k$ and $q$ are the specified lag lengths and are chosen on the basis of minimizing the Akaike Information Criterion. This is accomplished with the parsimonious $k=1, q=1$ where parameter $\beta_{0}$ is estimated at -1.22 (S.E. 0.6357 ), $\alpha_{1}$ is estimated at 0.1759 (S.E. 0.0972) and $\delta_{1}$ at 0.000828 (S.E. 0.000288). The estimation produces an $R^{2}$ value of $11.4 \%$ which indicates that the lagged variables only explain a small proportion of the variation in changes to the real trade weighted index. It is therefore concluded that other macroeconomic factors are highly influential over Australian Exchange rates. The specification yields residuals that appear free from autocorrelation at all standard significance levels using Lagrange Multiplier tests.

As the estimated relationship between RTWI and GDP is positive and significant, this suggests that on balance, the real side channel of influence, inclusive of terms of trade shocks, outweighs the monetary channel that implies a negative relationship. This is 
consistent with the econometric result from the previous sub-section that real side factors are more influential in determining exchange rates.

\section{Concluding Comments}

Despite the key role that exchange rate arrangements play in determining the effectiveness of monetary and fiscal policy, a consensus has yet to emerge on a theoretical framework for evaluating how particular exchange rate regimes should be chosen by governments with reference to their economies' macroeconomic characteristics. This paper contributes to understanding of this important issue by advancing a simple international macroeconomic framework for facilitating exchange rate regime choice for small economies facing real and monetary shocks.

It contends that if an economy is characteristically more prone to real shocks than monetary shocks, a floating exchange rate best minimizes its national income and hence employment variation, whereas a fixed exchange rate achieves this should monetary shocks be more significant than real ones. With reference to the Australian experience, the econometric results showed that Australia's independently floating exchange rate regime between 1985 and 2010 was optimal in light of the theory. 


\section{References}

Bosco, L. (1987). Determinants of Exchange Rate Regimes in LDC's: Some Empirical Evidence. Economic Notes, 10, 119-143.

Boyer, R. (1978) Financial Policies in an Open Economy. Economica 45, 39-57.

Branson, W. and Henderson, D. (1985) "The Specification and Influence of Asset Markets" in R. Jones and P. Kenen (eds) Handbook of International Economics, vol. 2, North Holland, Amsterdam.

Broda, C. (2001) Coping with Terms of Trade Shocks: Pegs versus Floats. American Economic Review, 91(May), 376-380.

Calvo, G. and Reinhart, C. (2002) Fear of Floating Quarterly Journal of Economics, 117, 379-408.

Dickey, D. and Fuller, W. (1979) Distributions of the estimators for autoregressive time series with a unit root. Journal of the American Statistical Association 74, 427431.

Eichengreen, B. (1995) The Endogeneity of Exchange Rate Regimes. In P. Kenen (ed.) Understanding Interdependence: The Macroeconomics of the Open Economy Princeton University Press, Princeton, NJ.

Elliott, G., Rothenberg, T. and, Stock, J. (1996) Efficient test for an autoregressive unit root. Econometrica 64, 813-836.

Engle, R. and Granger, C. (1987) Cointegration and Error-Correction: Representation, Estimation, and Testing. Econometrica, 55, 251-276.

Fleming, J. (1962) Domestic Financial Policy Under Fixed and Floating Exchange Rates. IMF Staff Papers, 9(3): 369-79.

Frenkel, J. (1976) "A Monetary Approach to the Exchange Rate: Doctrinal Aspects and Empirical Evidence", Scandinavian Journal of Economics, 78 (May), 200-224.

Garber, P. and Svensson, L. (1995) The Operation and Collapse of Fixed Exchange Rate Regimes in G. Grossman and K. Rogoff (eds.) Handbook of International Economics vol 3, Amsterdam, North Holland.

Genberg, H. (1989) Exchange Rate Management and Macroeconomic Policy: A National Perspective Scandinavian Journal of Economics 91, 439-69.

Hausmann, R., Panizza, U. and Stein, E. (2001) Why Do Countries Float the Way They Float? Journal of Development Economics, 66(4), 387-414.

Isard, P. (1995), Exchange Rate Economics., New York: Cambridge University Press. 
Mark, N. (1995), Exchange Rates and Fundamentals: Evidence on Long run Predictability. American Economic Review, 85(1), 201-218.

MacDonald, R. (1999) "Exchange Rate Behaviour: Are Fundamentals Important?" The Economic Journal, 109(459), 673-691.

MacKinnon, J. (1996) Numerical Distribution Functions for Unit Root and Cointegration Tests. Journal of Applied Econometrics, 11, 6, 601-618.

Makin, A. and Narayan, P. (2008) Have US External Imbalances Been Determined at Home or Abroad? Economic Modelling, 25, 520-531.

Melvin, M. (1985) Choice of an Exchange Rate System and Macroeconomic Stability. Journal of Money, Credit and Banking, 17(4), 467-478.

Mundell, R. (1963) Capital Mobility and Stabilization Policy Under Fixed and Flexible Exchange Rates. Canadian Journal of Economics and Political Science, 29, $4,475-85$.

Mussa, M. et al (2000) Exchange Rate Regimes in an Increasingly Integrated World Economy. IMF Occasional Paper 193, Washington, DC.

Nelson, C. and Plosser, C. (1982) Trends and random walks in macroeconomic time series. Journal of Monetary Economics, 10, 139-162.

Pappel, D. and Prodan, R. (2003) The uncertain unit root in US real GDP: Evidence with restricted and unrestricted structural change. Journal of Money Credit and Banking, 36, 423-427.

Phillips, P. and Ouliaris, S. (1990) Asymptotic Properties of Residual Based Tests for Cointegration. Econometrica, 58, 1, 165-193.

Phillips, P. and Perron, P. (1988) Testing for a Unit Root in Time Series Regression. Biometrika, 75, 335-346.

Poole, W. (1970) Optimal Choice of Monetary Policy Instruments in a Simple Stochastic Macro Model. Quarterly Journal of Economics, 84, 2, 197-216.

Rogoff, K. and others (2004) Evolution and Performance of Exchange Rate Regimes, IMF Occasional Paper 229, Washington, DC.

Said E. and Dickey, D. (1984) Testing for Unit Roots in Autoregressive Moving Average Models of Unknown Order. Biometrika, 71, 599-607.

Sarno, L. and Taylor, M. (2003) The Economics of Exchange Rates. Cambridge University Press, Cambridge. 